\title{
SANTEN-fuSe AS ANEARTHQUAKE DAMPER FOR PENDOPO JOGLO
}

\author{
MAER, Bisatya W. ${ }^{1 *}$, PUDJISURYADI, Pamuda ${ }^{2}$ \\ ${ }^{1}$ Department of Architecture, Faculty of Civil Engineering and Planning, Petra Christian University, \\ Jl. Siwalankerto 121-131, Surabaya 60236, INDONESIA \\ ${ }^{2}$ Department of Civil Engineering, Faculty of Civil Engineering and Planning, Petra Christian University \\ J1. Siwalankerto 121-131, Surabaya 60236, INDONESIA \\ *Corresponding author: mbm@petra.ac.id
}

\begin{abstract}
The 2006 Yogyakarta earthquake resulted in collapse of several traditional buildings in Yogyakarta, including joglos. This fact indicates that joglos are quite vulnerable to low-frequency ground shaking. The stability and rigidity of a joglo building are provided by the core of the building, i.e. the rong-rongan structure, in which connection of sakaguru (the column)-sunduk (the long span beam)-kili (the short span beam) has a rigid characteristic. This rigid rong-rongan structure behaves elastically during an earthquake event, and attracts large inertia force. This research aims to increase the structure performance of the rong-rongan by adding "SANTEN-fuse," an earthquake vibration damper, and by changing the joint connection of sakaguru-sunduk-kili to be that of a pin connection, but not changing the physical appearance of rong-rongan. Santen, whose function is to transfer the load of the roof from blandar to sunduk and from pangeret to kili, is modified so that it has frictional damper characteristic. This "SANTEN-fuse" can resist shear force up to certain level before it slides and acting as a damper. With the reduced stiffness, which leads to reduced inertia force, the overall structural responses are expected to be lower. An experimental quantitative method was used by doing a simulation using SAP2000 software to verify the idea. The pendopo dalem Yudonegaran a joglo house in Yogyakarta was chosen as a case study. Non-linear time history analysis was conducted. Simulation results showed that the proposed modification of rong-rongan structure by using "SANTEN-fuse", performed better than the original rong-rongan structure.
\end{abstract}

Keywords: Rong-rongan; SANTEN-fuse; non-linear time history analysis; structural responses.

\section{INTRODUCTION}

Pendopo joglo is one of the most valuable traditional architectural masterpieces in Indonesia that needs to be conserved. Pendopo is an important part of a traditional Javanese home, and is located at the front part of the house. The pendopo functions as a space to socialize with family members, relatives, and even neighbors, actualizing a form of harmony between the house inhabitants and the local community (Hidayatun, 1999), while joglo refers to a particular type of a traditional Javanese building.

The 2006 Yogyakarta earthquake resulted in the damage, even the destruction of some pendopo joglos. The pendopo joglo building consists of three parts (Figure 1a), i.e. the guru sector that is located in the centre of the plan, the pananggap sector that is located around the guru sector, and the emperl paningrat that is at theedge of pendopo surrounding the pananggapsector (Prijotomo, 2005). Figures 1a shows a pendopo joglo plan, while Figure $1 \mathrm{~b}$ shows the section of sakaguru, Figure 1c illustrates the three dimensional model of the building. In the guru sector, there is an element called rong-rongan, which is made up of four sakagurus, two pair of blandars, a pair of pangerets, a pair of sunduks, pair of kilis, and santens. On top of the rong-rongan is the tumpangsari, which consists of a stack of beams arranged in a formation that gradually widens to the top, and above the tumpangsari is usuk-usuk pandedel (Figure 1c, 2a). At the topmost part of rong-rongan there is blandar on the long side (c) and pangeret on the short side (f), see Figure 2b. Under blandar there is sunduk (b) and underneath pangeret there is kili (g). Between blandar and sunduk, also between pangeret and kili, at some rong-rongan there is santen (d). Prijotomo (2005) argued that santen's function is as a supplement, not in every rong-rongan there is santen. On rong-rongan with wide length, santen is placed to forward the roof weight and tumpangsari from blandar to sunduk/kili.The system of rong-rongan structure can perform as Moment Resistant Frame (MRF) because its stability and rigidity are formed by locking joint between sunduk-sakaguru (b dan a) and kili-sakaguru (g dan a), while the joint between sakablandar-pangeret is a pen and hole connection thus has pin joint characteristic (Figure 3). The Diagram of Momen in Figure 4 (Ronald, 1987) assured that the connection between saka-blandar-pangeret (a-c-f) has pin joint characteristic. 
In a research titled "Perilaku rumah tradisional Jawa joglo terhadap gempa" ("The performance of Javanese joglo buildings toward earthquake"), Prihatmaji (2007) proposed that joglo buildings were not stable in a low-frequency earthquakes, except when the support of sakaguru was changed into fixed support connection. The core structure that ensures the stability and rigidity of pendopo joglo is the rongrongan, which is located exactly in the centre of the building plan. The structure of rong-rongan can perform as the MRF with a pin support connection because the joint connection between saka-sunduk and saka-kili is a rigid joint. Inside of a few rongrongan structures, there is an additional component, which is santen, whose function is to transfer the load of the roof from blandar to sunduk and from pangeret to kili.

In this research, the structural concept of the MRF is changed by modifying santen's function to be the only lateral shear force support component as well as an earthquake vibration damper. The joints between saka-sunduk and saka-kili are changed to be pin joint connection, while the support of sakaguru remains pin support connection. This new model of santen with an altered function is labelled as "SANTEN-fuse" by the researchers of the current study. The name was chosen to reflect the fact that the idea was sparked by the shape and construction of santen. It is written in all capital to signify the different structural functions between SANTEN-fuse and santen. Finally, the word 'fuse' is commonly used in the earthquake engineering field to illustrate a particular component that is used to dissipatethe energy of an earthquake, a process that is similar to how an electrical fuse cuts out an electrical current when there is an overload.

This research aims to investigate that the SANTEN-fuse can improve the performance of rongrongan during an earthquake event-compared to the original rong-rongan structure.

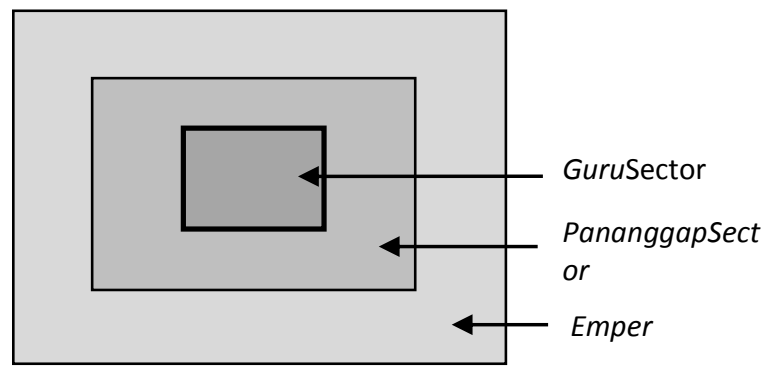

Figure 1a. Zonning in pendopo Joglo's plan (Cited from Prijotomo, 2005)

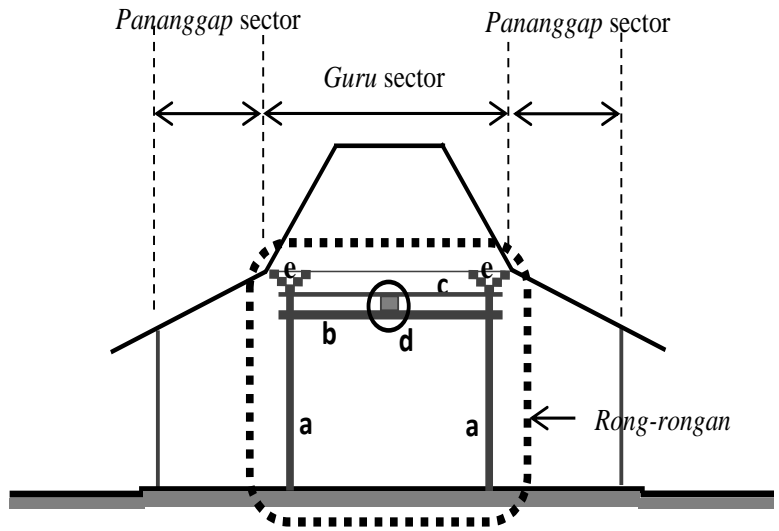

Figure 1b. The Section of Pendopo Joglo (Do not include the Figure of Emper)

$\mathrm{a}=$ saka, $\mathrm{b}=$ sunduk, $\mathrm{c}=$ blandar, $\mathrm{d}=$ santen, $\mathrm{e}=$ tumpangsari

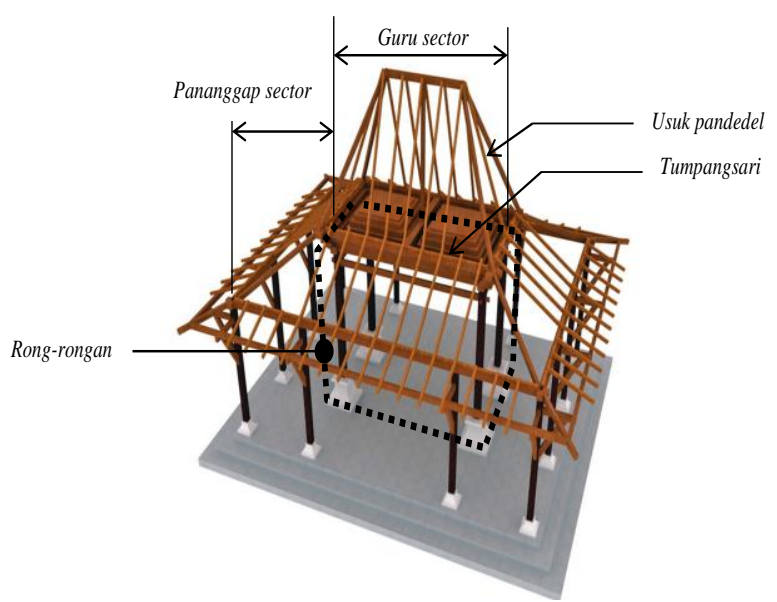

Source: http://achmad-jf.blogspot.com/2012/06/mengulas-sistemstruktur-joglo-dan-arti.html

Figure 1c. The Building Structure of Joglo (Excluding the Figure of Emper)

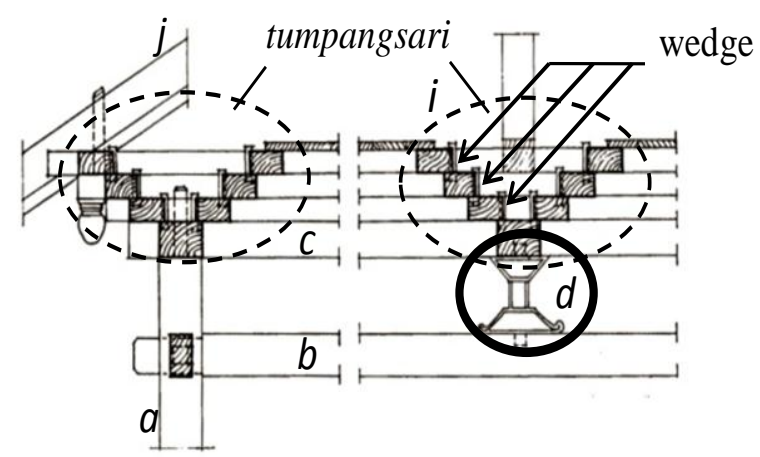

Source: Frick, 1997

Figure 2a. Section construction detail of tumpangsari $\mathrm{a}=$ saka, $\mathrm{b}=$ sunduk, $\mathrm{c}=$ blandar, $\mathrm{d}=$ santen, $\mathrm{i}=$ tumpangsari, $\mathrm{j}=$ usuk pandedel 


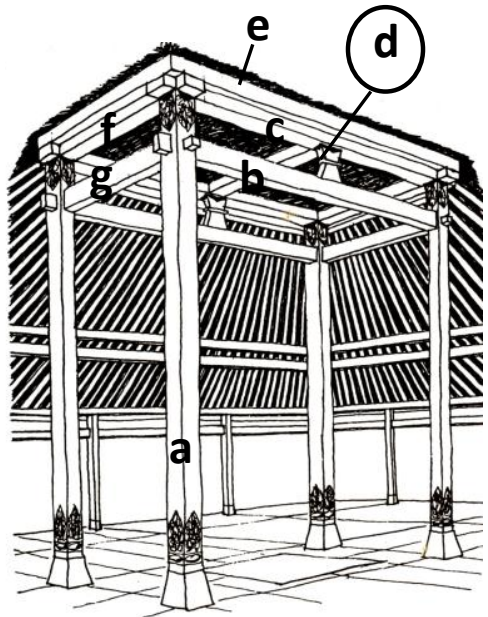

Source: Frick, 1997

Figure 2b. Rong-rongan structure $\mathrm{a}=$ saka, $\mathrm{b}=$ sunduk, $\mathrm{c}=$ blandar, $\mathrm{d}=$ santen, $\mathrm{e}=$ tumpangsari, $\mathrm{f}=$ pangeret, $\mathrm{g}=$ kili

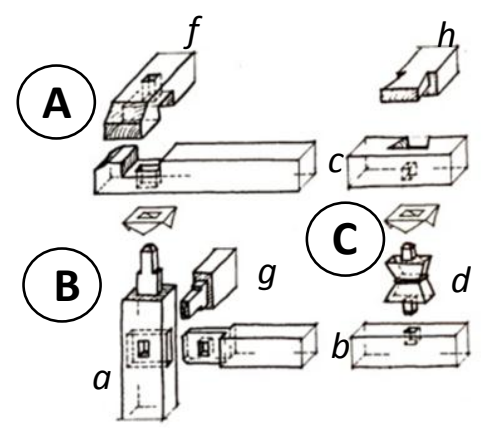

Source: Frick, 1997

Figure 3. Connection construction detail of saka-sundukkili (a-b-g); saka-blandar-pangeret (a-c-f); santen-blandarsunduk (d-c-b)

$a=$ saka, $b=$ sunduk, $c=$ blandar, $d=$ santen, $f=k i l i$, $g=$ pangeret,$h=$ dadapeksi)

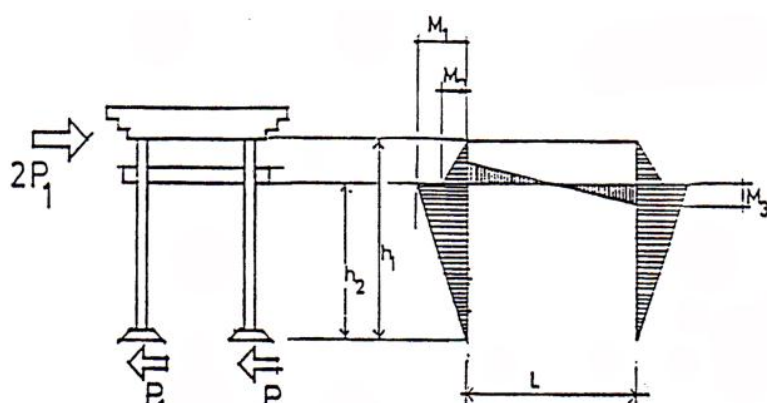

Source: Ronald, 1987

Gambar 4. Structural model and moment diagram of rongrongan.

\section{THEORETICAL FRAMEWORK}

Previously, the author has done a preliminary research: "Bisakah struktur rong-rongan rumah joglo hanya mengandalkan SANTEN?" ("Can rong-rongan structure of joglo house only rely on SANTEN?") (Maer, 2012). In this research, the model of rongrongan structure was modified to be a MRF Structure in which the stability and the rigidity were only supported by SANTEN. In the modified rong-rongan structure, the connections of saka-sunduk and sakakili are pin joint connections. The previous research has proven that the modified structure model can stand with stability and has more or less the same rigidity as the original rong-rongan structure model (Maer, 2012).

In a different perspective, Dowrick (1977) offered a more economical solution, namely designing the structure in a way so as to perform the dissipation of the earthquake force through an inelastic behavior. When the structure receives a high magnitude earthquake force, some critical parts of the structural components performed the dissipation of energy (yielding), so that some of the earthquake force is released. But wood itself, which is commonly used in Joglo structures, is not ideal for this purpose (non ductile material)

Wada (2004) recommended the usage of an additional tool or component in the structural elements which are able to perform the energy dissipation without resulting in a permanent damage on the structural components, one of which is the Passive Energy Dissipation Control System (PEDCS). There are two PEDCS systems, which are: 1) damping which depends on friction (displacement), and 2) damping which depends on velocity. Pin-Fuse Joint ${ }^{\mathrm{TM}}$ (Figure 5), patented by SOM (SOM Journal 4, p 69, 2004), is one example of PEDCS system usage with rotation friction damping.

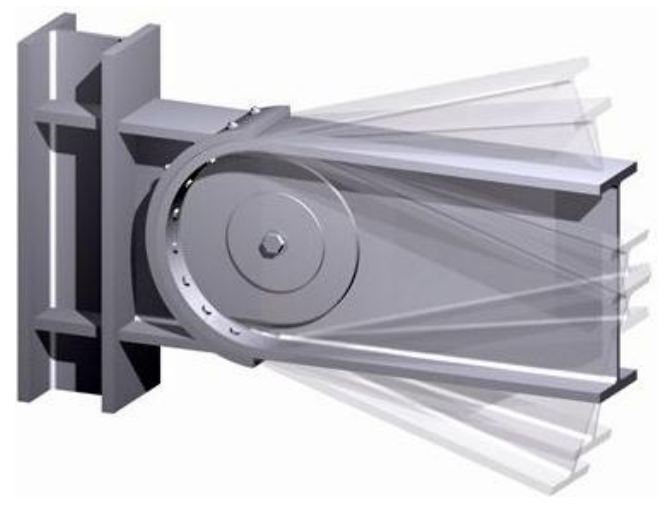

Source:http://designbythebay.com/wp-content/uploads/2010/12/ Glamour_Shot.jpg

Figure 5. Pin-Fuse Joint ${ }^{\text {TM }}$

In this research, SANTEN's function is developed to be PEDCS, where its damping character is 
provided through translational sliding (friction damper). In order to test this proposed system, simulations were conducted by using the SAP2000 software. Ground acceleration consistent to Indonesian earthquake response spectrum is used as the seismic load, and non-linear time history analysis were conducted. In the simulation, the performance of the experimental model of rong-rongan structure was compared to that of the performance of the original model of rong-rongan structure. The parameters used for comparisons were: the lateral deflections at the top of the rong-rongan, the shear force at sakaguru, the normal force at sakaguru, and the bending moment at sakaguru.

In developing the SANTEN-fuse, there are some considerations, as follows: 1) the overall the shape is kept relatively similar to the original santen; 2) the construction detail must be simple so that it is easy to build and repair; and 3) strong wood material should be used. With those considerations in mind, the shape and construction of SANTEN-fuse is proposed. The wood material should be class 2 or better (NI 5/PKKI 1978), and bolt specification according to type A325, with a dimension of $12 \mathrm{~mm}$. SANTEN-fuse is divided in the middle of its height; the top part is connected to blandar/pangeret, the bottom part is connected to sunduk/kili. The dimension and proportion of SANTEN-fuse is designed to perform mainly on resisting shear and not on bending moment. Blandar/pangeret, SANTEN-fuse, and sunduk/kili are assembled using pressure bolt which is placed in exactly at center of SANTEN-fuse's axis line.The hole for the pressure bolt on the top part of the SANTEN-fuse is designed to be loose in order to allow for movement space for the bolt. However, the hole for the pressure bolt on the bottom part of the SANTEN-fuse is designed to fit the bolt's diameter (Figure 6a1, 6a2, 6a3), and Figure 6b show SANTEN-fuse in slip position when receiving lateral shear force.

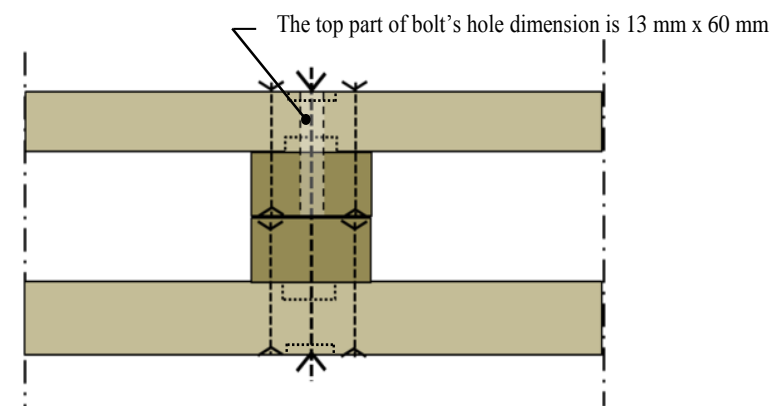

Figure 6a1. The front elevation of SANTEN-fuse construction

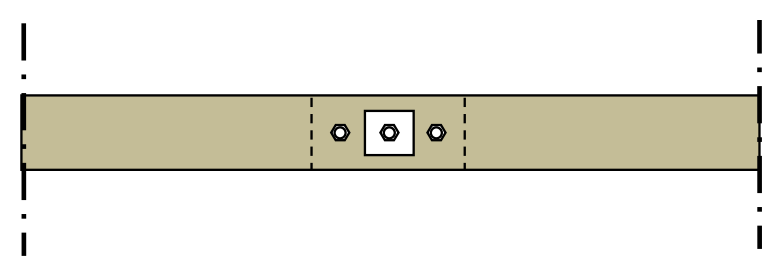

Figure 6a2. The plan of SANTEN-fuse construction

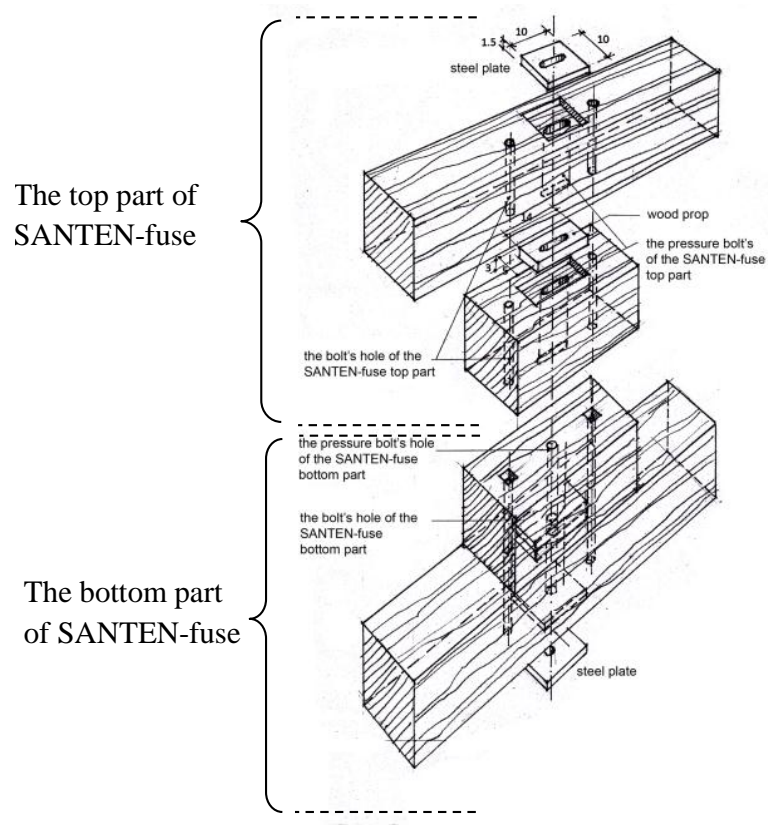

Figure 6a3. The perspektif of SANTEN-fuse construction

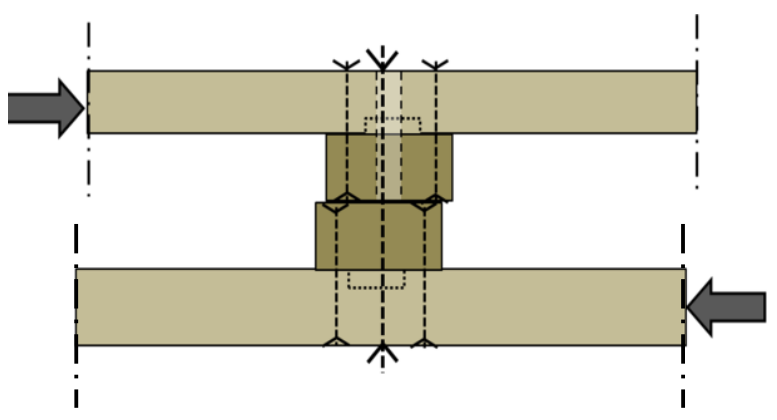

Figure 6b. SANTEN-fusein slip condition

This research is an experimental quantitative research with pendopo dalem Yudonegaran in Yogyakarta as the case study. This research is using Ronald's (1987) research titled "Joglo building: A study of construction, proportion and structure of royal houses in Yogyakarta" as a source for the case study. Ronald (1987) studied several types of traditional Javanese buildings in Yogyakarta, one of which was the pendopo dalem Yudonegaran. The pendopo dalem Yudonegaran was selected as a case study in the present research because this particular pendopo received the biggest bending moment at the sakaguru compared to the other structures. In this 


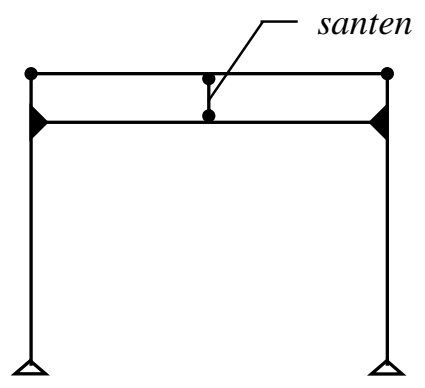

Note:

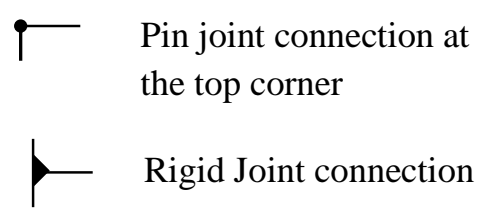

Figure 6a. Structure Model of $\mathbf{M}_{\mathbf{A}}$

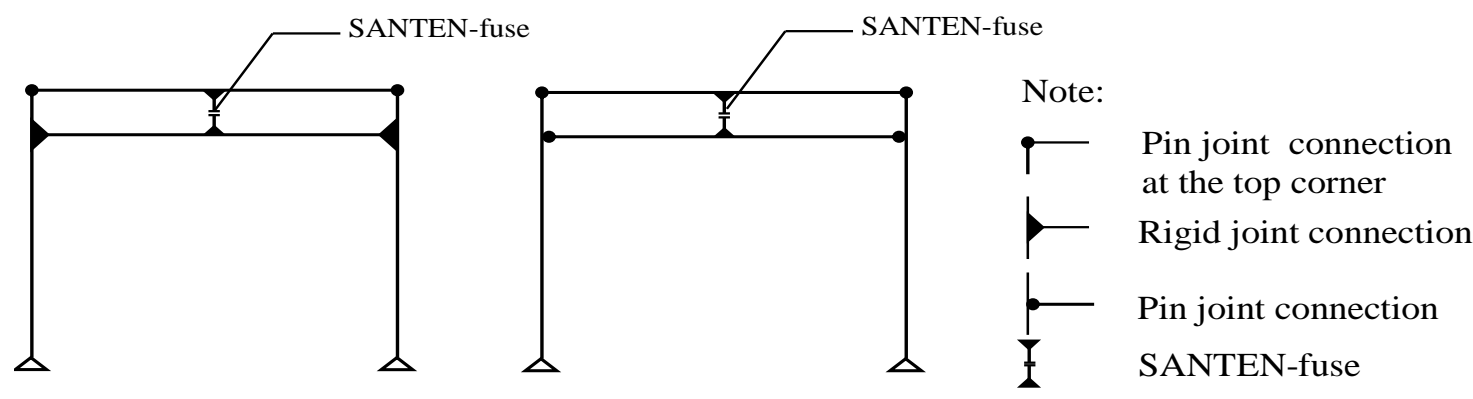

Figure 6a. Structure Model of $\mathbf{M}_{\mathrm{SF}-1} \quad$ Figure $\mathbf{6 b}$. Structure Model of $\mathbf{M}_{\mathrm{SF}-2}$

research, the performance between original model of rong-rongan structure $\mathbf{M}_{\mathbf{A}}$ (Figure 6a) is compared with two types experiment models of rong-rongan structure $\mathbf{M}_{\mathbf{S F}-1}$ dan $\mathbf{M}_{\mathbf{S F}-2}$. $\mathbf{M}_{\mathbf{S F}-1}$ is the original model of rong-rongan structure with SANTEN-fuse added (Figure $6 b) . \mathbf{M}_{\mathbf{S F}-2}$ is the modified model of rongrongan structure (the connections of saka-sunduk and saka-kili are pin joint connections) with SANTENfuse added (Figure 6c).

All three models of structure $\mathbf{M}_{\mathbf{A}}, \mathbf{M}_{\mathrm{SF}-1}$ and $\mathbf{M}_{\mathrm{SF} \text { - }}$ 2 were analyzed using SAP2000 software. To each model was given modified north-south El Centro earthquake acceleration input to produce acceleration response spectrum which consistent with Yogyakarta earthquake area in soft soils according SNI 2002. In those three models, rong-rongan is presumed supporting the whole seismic forces. The research consist 2 stages:

A. Comparing the performance of $\mathbf{M}_{\mathbf{A}}$ with $\mathbf{M}_{\mathrm{SF}-\mathrm{and}}$ and $\mathbf{M}_{\mathrm{SF}-2}$; and comparing the performance of $\mathbf{M}_{\mathrm{SF}-1}$ with $\mathbf{M}_{\mathrm{SF}-2}$.

B. Comparing the performance of $\mathbf{M}_{\mathrm{SF}-2}+1 \mathrm{pc}$ SANTEN-fuse, $\mathbf{M}_{\mathrm{SF}-2}+2$ pcs SANTEN-fuse, $\mathbf{M}_{\mathrm{SF}-2}+3$ pcs SANTEN-fuse, and $\mathbf{M}_{\mathrm{SF}-2}+4$ pcs SANTEN-fuse.

Below are the variables which determine the damping level of the SANTEN-fuseon rong-rongan structure:

- Rigid zone, which positioned at the meeting point between the SANTEN-fuse with blandarl pangeret and the SANTEN-fuse with sunduk/kili. Inside this rigid zone, there is no alteration of angle between the SANTEN-fuse with blandarl pangeret and the SANTEN-fuse with sunduk/kili. The wide variable of rigid zone is set based on width to length ratio of the SANTEN-fuse $(\mathrm{b} / \mathrm{h})=$ $0.2,0.5$, and 1. Physically, rigid zone depends on SANTEN-fuse's dimension and construction section. The SANTEN-fuse's dimension is determined based on: 1) the compressive strength of the wood towards the axial force of the pressure bolt; 2) the potential to perform rigid connecting behavior between SANTEN- fuse with blandar/ pangeret, and sunduk/kili; and 3) the ease in placing the bolt.

- Friction coefficient ( $\mu$-friction) at the interfaces of top-bottom of SANTEN-fuse. The friction coefficient was setas much as 0.2, 0.4 and 0.6.

- Axial compression force of SANTEN-fuse, which in turn depends on: 1) distributed load from the roof and tumpangsari on top of blandar, and 2) bolt tightening force $(25 \%, 35 \%, 50 \%$, and $75 \%$ of bolt allowable strength). If the roof structure and tumpangsari are set no resting on blandar, the axial compression force of the SANTEN-fuse comes only from bolt tightening force.

- Maximum slip (cm) is the amount of maximum slip depends on the width of rigid zone. In this research the maximum slip is expected to be less than $5 \mathrm{~cm}$. 


\section{THE OBSERVATION RESULTS AND MODEL SIMULATION STUDY}

The analysis result of Diagram-1 and Diagram-2 showed that $\mathbf{M}_{\mathbf{S F}-1}$ and $\mathbf{M}_{\mathbf{S F}-2}$ perform better than $\mathbf{M}_{\mathbf{A}}$, however the performance development of $\mathbf{M}_{\mathrm{SF}-2}$ towards $\mathbf{M}_{\mathbf{A}}$ is far more significant compared with the performance development of $\mathbf{M}_{\mathbf{S F}-1}$ towards $\mathbf{M}_{\mathbf{A}}$. In those two tables, all deflection values (d) of rongrongan, shear force $(\mathrm{V})$ of sakaguru, normal force $(\mathrm{N})$ of sakaguru and momen (M) of sakaguruwhich happened to $\mathbf{M}_{\mathbf{S F}-1}$ and $\mathbf{M}_{\mathrm{SF}-2}$ is smaller than that which happened to $\mathbf{M}_{\mathbf{A}}$. Meanwhile, all of those values on $\mathbf{M}_{\mathbf{S F}-2}$ are smaller than on $\mathbf{M}_{\mathbf{S F}-1}$. This result shows that the performance of $\mathbf{M}_{\mathbf{S F}-2}$ is the most optimum compared with $\mathbf{M}_{\mathbf{S F}-1}$ and $\mathbf{M}_{\mathbf{A}}$.

The dissimilarity between the two performances was caused by the fixed rigidity of $\mathbf{M}_{\mathrm{SF}-1}$ which came from rigid joint connection between sakagurusunduk-kili, while $\mathbf{M}_{\mathbf{S F}-2}$ structure rigidity only occurred because of the tightness of SANTEN-fuse (the $\mu$-friction magnitude and axial force). When $\mathbf{M}_{\mathbf{S F}}$ 1's SANTEN-fuse is tightened or loosened by increasing or decreasing the $\mu$-friction and/or the axial force of SANTEN-fuse, the result of $\mathbf{M}_{\mathrm{SF}-1}$ structure rigidity is not significant compared to $\mathbf{M}_{\mathbf{S F}-2}$ in the same treatment. This resulted in the increase or decrease of the earthquake acceleration non linear time history response of $\mathbf{M}_{\mathbf{S F}-1}$ to also be not significant compared to $\mathbf{M}_{\mathbf{S F}-2 \text {. }}$

The next interest is whether the different number of SANTEN-fuse caused significant effect towards $\mathbf{M}_{\mathrm{SF}-2}$ performance. The analysis of the results is summarized and simplified in Graphic-1 which shows the relationship between the magnitude of V slip of SANTEN-fuse and the maximum slip of SANTENfuse in $\mathbf{M}_{\mathrm{SF}-2}$ with 1 piece, 2 pieces, 3 pieces and 4 pieces SANTEN-fuse. Graphic-2 shows the relationship between the magnitude of V slip of SANTENfuse and maximum deflection at the top of rongronganof $\mathbf{M}_{\mathrm{SF}-2}$ with 1 piece, 2 pieces, 3 pieces and 4 pieces SANTEN-fuse.

Observed is categorized in three $\mathrm{V}$ slip group magnitudes, namely: $1000 \mathrm{kgf} \mathrm{V}$ slip, approximately $1400-1500 \mathrm{kgf}$ V slip, and $6000 \mathrm{kgf}$ V slip. These three groups show a trend of inconsistencies on the magnitude of the maxium slip of SANTEN-fuse and the maximum deflectionof $\mathbf{M}_{\mathbf{S F}-2}$. It seems that this phenomenon is the uniqueness of the non-linier structure: when $\mathbf{M}_{\mathbf{S F - 2}}$ is slipping, its condition becomes non-linear. In that condition, when $\mathbf{M}_{\mathrm{SF}-2}$ receives non-linear time history earthquake acceleration, it is unclear whether it was the $\mu$-friction, SANTEN-fuse axial force or the amount of
SANTEN-fuse which significantly resulted in maximum slip, deflection at the top of rong-rongan, shear force on sakaguru, axial force on sakaguru and moment on sakaguru.

\section{CONCLUSION}

SANTEN-fuse addition can increase the performance of $\mathbf{M}_{\mathrm{SF}-1}$ and $\mathbf{M}_{\mathrm{SF}-2}$ structure models to be better than original structure model $\mathbf{M}_{\mathbf{A}}$. The addition of SANTEN-fuse is more optimal if applied to rongrongan structure with pin joint connection between sakaguru-sunduk-kili that is similar to modified rongrongan structure ( $\left.\mathbf{M}_{\mathbf{S F}-2}\right)$ compared with rong-rongan structure with rigid joint between sakaguru-sunduk kili that is similar to original rong-rongan structure $\left(\mathbf{M}_{\mathrm{SF}-1}\right)$. The number/amount of SANTEN-fuse is not significant in determining the structure model $\mathbf{M}_{\mathbf{S F}-2}$ result level.

\section{RECOMMENDATIONS}

The usage of SANTEN-fuse is recommended especially for modified rong-rongan structure where the connection between sakaguru-sunduk-kili uses pin joint connection. The addition of SANTEN-fuse can be applied to both the new pendopo joglo construction and the existing pendopo joglo to improve its performance. However, special designed construction of SANTEN-fuse (SANTEN-fuse dimension, bolt dimension, tightness level of bolt) needs to be done for each pendopo joglo building and different earthquake area.

The addition of SANTEN-fuse to existing pendopo joglo without changing joint construction between sakaguru-sunduk-kili can be done although the result will be less effective than if the construction joint between sakaguru-sunduk-kili is changed into pin joint.

Results from this study have shown that it is possible to create an "earthquake friendly" structure in joglo buldings. It is recommended that future research in this field should focus on:

- The effect of changing the structural function of santen to SANTEN-fuse in relation to the architectural meaning of pendopo Joglo.

- Detailed construction design of joint between sakaguru-sunduk-kili which is changed into pin joint.

- The bolt tightening application for SANTEN-fuse is still limited to this research and cannot be generalized for actual use yet. Further research should be conducted to formulate the conversion table of bolt torque moment (the result of bolt tightening with torque wrench) to axial force. 
- This research is developed based on secondary literature data; therefore, there is a possibility that some of the experimental conditions may not reflect real-life situations. Thus, this also opens an opportunity for further field study.

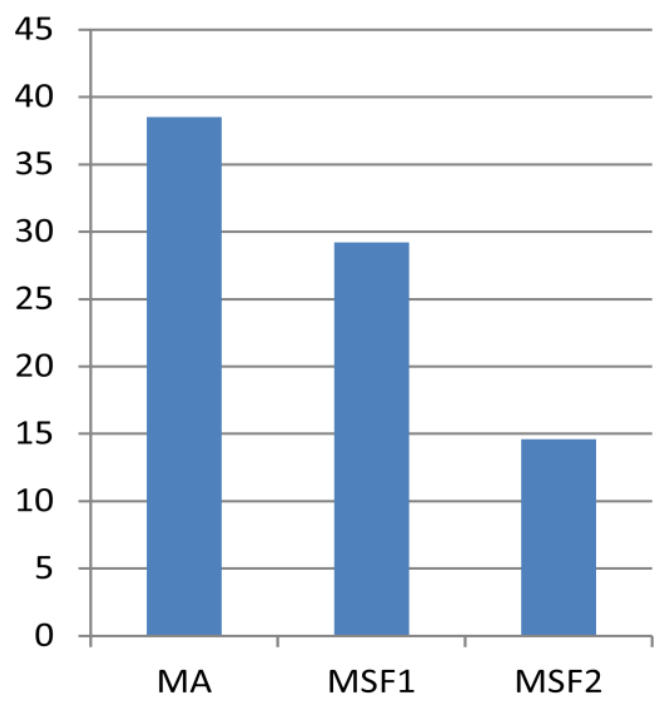

Diagram 1. Maximum Deflection on the models: MA, MSF-1, MSF-2

Note:

The vertical axis $=$ maximum deflection at the top of rongrongan, in $\mathrm{cm}$. The horizontal axis $=$ the type of the models

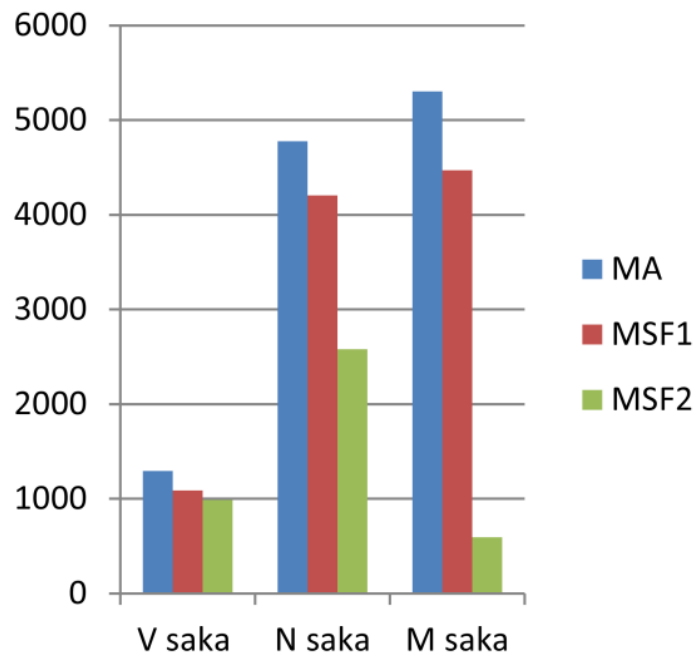

Diagram 2. Maximum Shear Force of Sakaguru (V saka), Axial Force of Sakaguru (N saka), and Moment of Sakaguru (M saka) on MA, MSF-1, MSF-2

Note:

The vertical axis $=$ the magnitude of shear force $(\mathrm{V}$, in $\mathrm{kgf})$, axial force ( $\mathrm{N}$, in kgf), Moment $\mathrm{M}$, in $\mathrm{kgf} \mathrm{m}$ ) of sakaguru

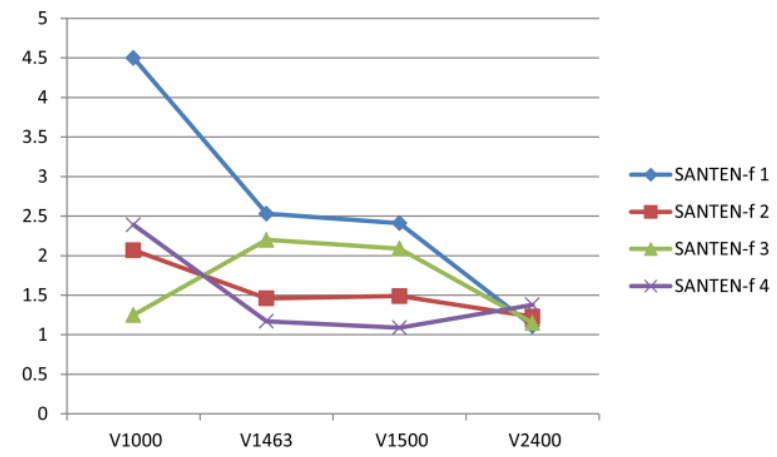

Graphic 1. Maksimum Slip of SANTEN-fuse vs V slip, for $\mu$ Friction $=0.4$, On $\mathrm{M}_{\mathrm{SF}-2}$ with 1 pcs., 2 pcs., 3 pcs., 4 pcs. SANTEN-fuse

\section{Note:}

- The vertikal axis = maximum slip in $\mathrm{cm}$

- The horizontal axis = V slip in kgf; V $1000=$ the magnitude of V slip $=1000 \mathrm{kgf}, \mathrm{V} 1463=$ the magnitude of V slip $=1463 \mathrm{kgf}, \mathrm{V} 1500=$ the magnitude of V slip $=1500 \mathrm{kgf}, \mathrm{V} 2400=$ the magnitude of V slip $=2400 \mathrm{kgf}$.

- SANTEN-f1 = the amount of SANTEN-fuse is 1 pcs., SANTEN-f $2=$ the amount of SANTEN-fuse is 2 pcs., SANTEN-f3 $=$ the amount of SANTEN-fuse is 3 pcs., SANTEN-f $4=$ the amount of SANTEN-fuse is 4 pcs.

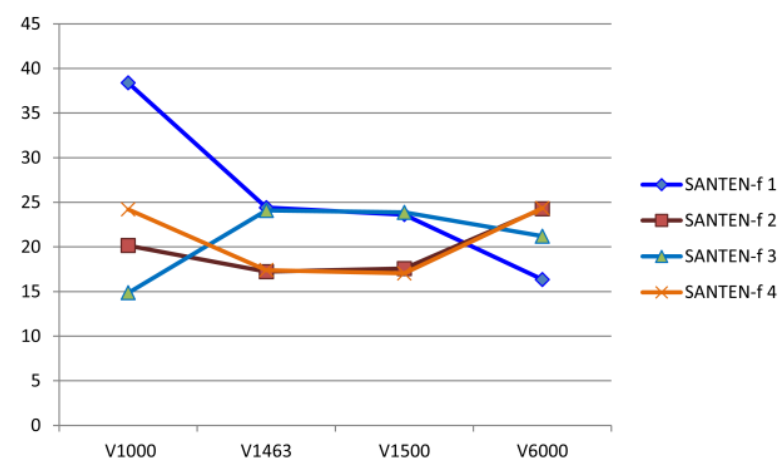

Graphic 2. Maksimum Top Deflection vs V slip, for $\mu$ Friction $=0.4$, On $\mathrm{M}_{\mathrm{SF}-2}$ with 1 pcs, 2 pcs., 3 pcs., 4 pcs. SANTEN-fuse

Note:

- The vertical axis = maximumtop deflection in $\mathrm{cm}$

- The horizontal axis = V slip in kgf;V $1000=$ the magnitude of V slip $=1000 \mathrm{kgf}, \mathrm{V} 1463=$ the magnitude of V slip $=1463 \mathrm{kgf}, \mathrm{V} 1500=$ the magnitude of $\mathrm{V}$ slip $=1500 \mathrm{kgf}, \mathrm{V} 6000=$ the magnitude of V slip $=6000 \mathrm{kgf}$.

- SANTEN-f1 $=$ the amount of SANTEN-fuse is 1 pcs., SANTEN-f $2=$ the amount of SANTEN-fuse is 2 pcs., SANTEN-f3 $=$ the amount of SANTEN-fuse is 3 pcs., SANTEN-f4 $=$ the amount of SANTEN-fuse is 4 pcs. 


\section{REFERENCES}

Arnold, C. and Reitherman, R. (1982). Building configuration and seismic design. New York: John Wiley \& Sons.

Charleson, A. (2008). Seismic design for Architects, Outwitting the quake. Amsterdam: Elsevier Ltd.

Dowrick, D.J. (1977). Earthquake resistant design, a manual for engineers and architects. New York: John Wiley \& Sons.

Frick, H. (1997). Pola struktural dan teknik bangunan di Indonesia ("Structural patterns and building technique in Indonesia"). Penerbit Kanisius

Hidayatun, M. I. (1999). Pendopo dalam era modernisasi, bentuk fungsi dan makna pendopo pada arsitektur tradisional jawa dalam perubahan kebudayaan ("Pendopo in the era of modernization, the shape function and meaning of the Javanese traditional pendopo architecture in culture change"). Journal Dimensi, 27(1), 3747.

Maer, B .W. (2012). Bisakah struktur rong-rongan rumah joglo hanya mengandalkan "SANTEN"? ("Can Rong-rongan Structure of Joglo House Only Rely on SANTEN?"). National Conference paper presented at The $45^{\text {th }}$ Anniversary of
The Department of Architecture Petra Christian University, "Menuju arsitektur berempati" ("Towards the emphatic architecture").

Prihatmaji, Y. P. (2007). Perilaku rumah tradisional jawa Joglo terhadap gempa (The performance of Javanese Joglo Buildings toward earthquake). Jurnal Dimensi, 35(1), 1-12.

Prijotomo, J. (2005). Pengkonstruksian sektor guru dari griya Jawa: tafsir atas kawruh kalang (Constructing the guru sector of griya Jawa: interpretations of kawruh kalang). Journal Dimensi, 33(2), 99-111.

Ronald, A., Santosa, M. and Soeleman. (1987). Joglo building a study of construction, proportion and structure of royal houses in Yogyakarta. Department of Architecture Engineering UGM.

US Patent No 6,681,538 B1. (2004). Pin-Fuse Joint $^{T M}$. SOM Journal, 4, 69.

Wada, A., Huang, Y. and Bertero, V. V. (2004). Innovative Strategies in Earthquake Enineering. In Bozorgnia, Yousef \& Betero, Vitelmo V (Eds). Earthquake engineering, from engineering seismology to performance-base enginering (p.10-1 and 10-29), New York Washington, D.C: CRC Press. 